\title{
Bertrand De La Borderie, Le Discours du voyage de Constantinoble (1542)
}

\section{Rosa Galli Pellegrini}

\section{Q OpenEdition}

1 Journals

\section{Edizione digitale}

URL: https://journals.openedition.org/studifrancesi/40438

DOI: 10.4000/studifrancesi.40438

ISSN: 2421-5856

\section{Editore}

Rosenberg \& Sellier

\section{Edizione cartacea}

Data di pubblicazione: 1 juillet 2004

Paginazione: 170

ISSN: 0039-2944

\section{Notizia bibliografica digitale}

Rosa Galli Pellegrini, «Bertrand De La Borderie, Le Discours du voyage de Constantinoble (1542)», Studi Francesi [Online], 142 (XLVIII | I) | 2004, online dal 30 novembre 2015, consultato il 09 septembre 2021. URL: http://journals.openedition.org/studifrancesi/40438; DOI: https://doi.org/10.4000/studifrancesi. 40438

Questo documento è stato generato automaticamente il 9 septembre 2021.

\section{(c) 9 (i) $\Theta$}

Studi Francesi è distribuita con Licenza Creative Commons Attribuzione - Non commerciale - Non opere derivate 4.0 Internazionale. 


\section{Bertrand De La Borderie, Le Discours du voyage de Constantinoble (1542)}

Rosa Galli Pellegrini 


\section{NOTIZIA}

BERTRAND DE LA BORDERIE, Le Discours du voyage de Constantinoble (1542), édition critique par CHRISTIAN BARATAUD et DANIELLE TRUDEAU, Paris, Champion, 2003, pp. 256.

1 Il testo del Discours di La Borderle, più volte riedito nel Cinquecento, ma fondamentalmente misconosciuto dagli studiosi, meritava una edizione critica. La meritevole fatica dei curatori offre un'ottimo prodotto, che mette in risalto i numerosi aspetti originali di questo testo. Un'ampia introduzione affronta l'analisi del poema (1768 versi) collocandolo innanzittutto nella politica del periodo e dei rapporti di Francesco I con l'Impero Ottomano, con Venezia e con Carlo V. La successiva lettura interna inizia con la discussione sul "genere» dell'opera e con il richiamo ai suoi eventuali modelli latini (in particolar modo l'Ovidio delle Héroides et delle Tristia), per passare via via al suo significato in quanto epistola di viaggio e alla contaminazione dei generi che vi si trova: discorso, mito, elegia.

2 Infine gli AA. considerano il poema anche come un «romanzo» iniziatico. I curatori tendono comunque a collocare di preferenza il Discours nella politica della traslatio imperii sostenuta da Francesco I e del conseguente appoggio alla cultura e alla «illustration» della lingua volgare perseguita dai letterati del tempo.

3 L'ampio apparato critico rende conto della grafia e della lingua e arricchisce il testo di numerose note. Vi si annettono poi alcuni passi tratti da altri viaggiatori del XVI secolo, che, in qualche modo possono essere collegabili ai Discours. Infine un glossario e un indice delle figure mitologiche può essere utile ad un uso didattico del testo, mentre manca un indice dei luoghi e dei personaggi storici, (che sarebbe stato molto utile e che era stato annunciato sulla versione in rete), i quali sono stati invece messi nell'indice dei nomi. Una ricca bibliografia conclude la pregiata edizone. 